\title{
A Reconstruction of Transnational Legal Pluralism and Law's Foundations
}

\author{
BRIAN Z. TAMANAHA
}

An outpouring of writings on global or transnational legal pluralism has occurred in the past two decades. Despite its apparent popularity, however, it suffers from deep conceptual problems. After reviewing two decades of this proliferating literature, jurisprudent William Twining remarked, 'I have come away feeling that it is little better than a morass'. This chapter is an attempt to clear up the morass. Three complicating factors bear mention at the outset. First, 'pluralism' is a capacious term that simply means two or more and can be applied to law in a multitude of ways. Second, 'law' is a contested notion that has been conceived of in numerous ways. Third, legal pluralism has been invoked in a variety of fields with very different orientations and objectives, including legal anthropology, legal sociology, postcolonial studies, law and development, human rights, comparative law, international law, transnational law and jurisprudence. The confluence of these factors has resulted in a tangled conceptual mess.

With these preliminary comments in mind, I address a series of central issues bearing on global/transnational legal pluralism (labels used interchangeably). The first several parts of this chapter critically examine certain prominent positions in global legal pluralism, showing why they are problematic, after which I construct an alternative account that avoids these problems. First, I demonstrate that, contrary to current accounts, global legal pluralism is not continuous with earlier versions of (postcolonial and sociological) legal pluralism; these are three completely distinct paradigms. Next, I expose the flaw of overinclusiveness that has plagued theoretical conceptions of legal pluralism from the

For their helpful critical comments on earlier drafts, I thank Nico Krisch, Hanna Birkenkotter, Sarah Nouwen and Ralf Michaels.

${ }^{1}$ W. Twining, 'Normative and Legal Pluralism: A Global Perspective' (2010) 20 Duke Journal of Comparative and International Law 473-518, at 487. 
outset and reappears in global legal pluralism, particularly in the work of Paul Berman. Then I show why theoretical concepts of law cannot solve this flaw, which ultimately led John Griffiths - the foremost champion of legal pluralism - to repudiate the notion. I then address the profusion of private and hybrid regulatory forms on the domestic and transnational levels, and I mark the line between theory and practice. Thereafter, I expose problems with the relational concept of law formulated by Ralf Michaels, showing why it is unsuitable for many situations of legal pluralism. These critical examinations lay a basis for the constructive account that follows. The approach to legal pluralism I articulate involves social constructions conventionally identified as law that vary and change over time, which can be grouped in terms of three categories: community law, regime law and cross-polity law. Finally, I set forth a handful of specific lessons for a reconstructed transnational legal pluralism.

\subsection{Three Distinct Paradigms of Legal Pluralism}

It is common to characterize attention to legal pluralism as three successive waves building on earlier work: first came attention by anthropologists to postcolonial legal pluralism, then attention by sociologists to legal pluralism in every society, then attention by jurists to global/transnational legal pluralism. Global legal pluralist Ralf Michaels observed:

Legal pluralism, long a special interest within the specialist discipline of legal anthropology, has recently moved into the mainstream of legal discourse. The most likely reason is globalization. Many of the challenges that globalization poses to traditional legal thought closely resemble those formulated earlier by legal pluralists. The irreducible plurality of legal orders in the world, the coexistence of domestic state law with other legal orders, the absence of a hierarchically superior position transcending the differences - all of these topics of legal pluralism reappear on the global sphere. $^{2}$

This narrative of continuity is reinforced by frequent references in the third approach to major theorists and theories within the second approach, prominently including John Griffiths (anti-legal centralism, strong versus weak legal pluralism), Eugen Ehrlich (living law of social associations) and Sally Falk Moore (semi-autonomous social field).

2 R. Michaels, 'Global Legal Pluralism' (2009) 5 Annual Review of Law and Social Sciences $243-62$, at 244. 
This narrative, however, is misleading. Other than being about 'law' (though in different senses) and shining the spotlight on 'pluralism' (albeit in different senses), these three approaches have little in common. John Griffiths, the leading proponent of the second approach, pointedly rejected the first approach. He labelled postcolonial legal pluralism 'weak' because it involved recognition by the state of customary law, which Griffiths construed as merely reinforcing legal centralism. "Legal pluralism" in the weak [postcolonial] sense has little to do with the concept of legal pluralism which is the subject of this article, ${ }^{3}$ he declared, sharply distancing his sociological conception from studies of postcolonial law.

Griffiths' essay centres on 'strong' legal pluralism - 'an empirical state of affairs, namely the coexistence within a social group of legal orders which do not belong to a single system, ${ }^{4}$ This legal pluralism is based on a sociological concept of law, which encompasses the normative ordering of social associations and institutionalized rule systems generally (more on this shortly). As Sally Engle Merry noted three decades ago in her astute overview of legal pluralism, which boosted its academic profile, these two contexts of legal pluralism 'make odd companions' in that they have different targets and 'they come out of different scholarly traditions. ${ }^{5}$ In Kuhnian terms, this is a revolutionary paradigm shift, not a cumulative building on previous insights.

Comparative, international and transnational legal scholars who came to legal pluralism changed the subject yet again, in multiple ways. Contemporary global/transnational legal pluralism is the product mainly of jurists who focus on public and private systems of law and regulation between and across states, giving rise to multiple coexisting regulatory forms with potential application in various contexts. Constitutional pluralism of the European Union involves the pluralism of coexisting, intertwined official systems of national and EU law; international legal pluralism (or fragmentation) involves a pluralism of different subject matter regimes and tribunals within international law. None of this resembles postcolonial legal pluralism or sociological legal pluralism.

The characteristic feature of postcolonial legal pluralism is the coexistence of bodies of law with profoundly different norms and processes mainly state law, and customary and religious law - operating

3 J. Griffiths, 'What Is Legal Pluralism?' (1986) 24 Journal of Legal Pluralism 1-56, at 8.

4 Ibid., 8.

5 S. E. Merry, 'Legal Pluralism' (1988) 22 Law \& Society Review 869-96, at 874. 
independently as well as intertwined in various ways. A report issued by the World Bank legal department observes:

In many developing countries, customary systems operating outside of the state regime are often the dominant form of regulation and dispute resolution, covering up to $90 \%$ of the population in parts of Africa. In Sierra Leone, for example, approximately $85 \%$ of the population falls under the jurisdiction of customary law, defined under the Constitution as 'the rules which, by custom, are applicable to particular communities in Sierra Leone'. Customary tenure covers $75 \%$ of land in most African countries, affecting $90 \%$ of land transactions in countries like Mozambique and Ghana [...] In many of these countries, systems of justice seem to operate almost completely independently of the official state system. ${ }^{6}$

Many manifestations of customary law involve the application of informal (unwritten) legal norms by chiefs or village elders, with the participation of members of the community, oriented towards resolving the matter, taking into consideration not just the individuals and specific incident involved, but also broader social relations. In contrast, state law involves transplanted, formal legal norms applied by legal officials within legal institutions utilizing technical legal terminology and processes.

What stands out about postcolonial legal pluralism is not the multiplicity of law per se, but rather the stark contrasts and sheer diversity between the coexisting bodies of formal and informal law derived from different traditions involving fundamentally different world views (in certain respects incompatible), reflecting highly fragmented societies (ethnic, religious, urban/rural, educated/illiterate, commercial developers/subsistence farmers, etc.). Compare this with discussions in the global/transnational legal pluralism literature of the interaction between EU law and national law, the TRIPS (Trade-Related Aspects of Intellectual Property Rights) agreement, lex mercatoria, human rights, World Trade Organization (WTO) law and the Appellate Body, Codex Alimentarius, UNIDROIT, lex sportiva and so forth. What stands out about the latter group is the burgeoning multiplicity of transnational legal and regulatory regimes, many tied to the expansion of global capitalism. While these norms and bodies of law may conflict in various ways, they are virtually all Western derived and they involve formal written regulatory regimes and tribunals operating in standard ways familiar to jurists.

${ }^{6}$ L. Chirayath, C. Sage, and M. Woolcock, Customary Law and Policy Reform: Engaging with the Plurality of Justice Systems (World Bank Legal Department Paper, 2005), p. 3. 
The point, again, is that these situations of legal pluralism have very little in common. The claim of continuity between the first (postcolonial) and third (global) approaches to legal pluralism trades on two distinct connotations of pluralism: diversity and multiplicity. The former is fundamentally about legal diversity while the latter is about legal multiplicity. The former is largely the product of legal anthropologists exploring the various social consequences of these contrasting coexisting bodies of law; and most of these works are not juristically oriented. The latter largely involves academic jurists - many of whom are Europeans grappling with the interaction between EU law and national law - focusing on harmonization, reconciliation, assimilation, discussing choice of law and conflicts of law, jurisdiction and the like.

The differences between the second (sociological) and third (global) approaches to legal pluralism are also substantial - again grounded in fundamentally different orientations and objectives. The second approach was pioneered by sociologists whose goal was to construct a science of society around a sociological concept of law. A scientific positivist, John Griffiths was explicit about this objective:

Thus, if concepts such as law, legalness, and social control are to figure in sociological theory, they must be taken as referring to identifiable social facts, and variation in those social facts should ultimately be expressible in quantitative terms.

The first problem for the sociology of law, given the preceding assumptions, is to identify the sort of social fact it takes as its subject matter. ${ }^{7}$

Griffiths believed that (strong) legal pluralism follows directly from a sociological conception of law, and thus (strong) legal pluralism provides a basis for the sociology of law.

Among global/transnational legal pluralists, Gunther Teubner early on constructed legal pluralism in terms of a science of society (taking off from Griffiths and Sally Falk Moore), applying his autopoietic theory of law as a communicative system to transnational law, ${ }^{8}$ advocating that 'legal pluralism needs to shift emphasis and focus on the fragmentation of social reproduction in a multiplicity of closed discourses'.9 A second

7 J. Griffiths, 'The Division of Labor in Social Control', in D. Black (ed.), Toward a General Theory of Social Control (Academic Press, 1984), pp. 37-70, at p. 39 (italics added).

${ }^{8}$ G. Teubner, 'Two Faces of Janus: Rethinking Legal Pluralism' (1991) 13 Cardozo Law Review 1443-62.

9 Ibid., 1457. 
early theorist of transnational legal pluralism, Boaventura de Sousa Santos, also had a sociological orientation, though from a postmodern perspective that eschewed a systematic science of society. ${ }^{10}$ However, most contemporary global/transnational legal pluralists are not sociologists engaged in scientific theorizing about law, but are academic jurists largely focusing on, mapping and grappling with the multiplicity of transnational regulatory forms and their various modes of interaction and entanglement. ${ }^{11}$ Owing to these different backgrounds and objectives, what the second (sociological) approach to legal pluralism is about is radically different from what the third (global) approach is about. Understood on its own terms, this latest take on legal pluralism represents yet another revolutionary paradigm change. The only connective link is that global legal pluralists regularly refer to the work of Griffiths, Moore and Ehrlich, derived from the sociological approach. This link, however, gives rise to irresolvable conceptual difficulties and disputes and should be discarded for reasons I explain in Sections 17.2 and 17.3.

William Twining, who has written extensively about globalization as well as about legal pluralism, ${ }^{12}$ found that the many extensions and applications of the idea of legal pluralism to new phenomena and situations are so many and so varied that it is difficult to construct a coherent answer to the question: what is the relevance of classical studies of legal pluralism to the emerging field of "global legal pluralism"? ${ }^{13}$ My point is that any relevance is minimal. ${ }^{14}$

\subsection{The Overinclusiveness Flaw}

In her 1988 overview of legal pluralism, Sally Merry flagged a conceptual flaw of sociological legal pluralism that has reappeared in global legal pluralism in the writings of Paul Berman. Merry remarked, 'Where do we

10 B. de Sousa Santos, 'Law: A Map of Misreading - Toward a Postmodern Conception of Law' (1987) 14 Journal of Law and Society 279-302; B. de Sousa Santos, Toward a New Common Sense: Law, Science and Politics in the Paradigmatic Transition (Routledge, 1995).

11 See Chapter 1.

12 See W. Twining, General Jurisprudence: Understanding Law from a Global Perspective (Cambridge University Press, 2009).

13 Twining, 'Normative and Legal Pluralism', 512-13.

14 Twining denied 'any strong claims to continuity', though he observed that global legal pluralism exhibited a similar opposition to state centrism, recognition of non-state law, taking religion seriously and more of an empirical orientation. Ibid., 515. 
stop speaking of law and find ourselves simply describing social life? Is it useful to call all these forms of ordering law? I find that once legal centralism has been vanquished, calling all forms of ordering that are not state law by the term law confounds the analysis. ${ }^{15}$ The sociological conception of legal pluralism construes the normative ordering of social associations (like the family) and institutionalized rule systems (like corporations and universities) as forms of law. In Section 17.3, I explain the source of this problem and why it cannot be resolved, but here I flag its appearance in global legal pluralism.

Paul Berman, a prolific contemporary theorist of global legal pluralism, asserts that there is no need to define law. Yet, in effect, he presupposes a conception of law tied to social associations, but without explicitly articulating it. ${ }^{16}$ Berman identifies law with norm-generating communities: 'From religious institutions, to industry standard-setting bodies to not-for-profit accreditation entities to arbitral panels to university tenure committees to codes promulgated within ethnic enclaves to self-regulation regimes in semi-autonomous communities, the sites of non-state lawmaking are truly everywhere. ${ }^{17}$ (His reference to selfregulation of semi-autonomous communities incorporates Sally Falk Moore's analysis, which I take up in Section 17.3) Berman has also identified law within the family ${ }^{18}$ and 'in day-to-day human encounters such as interacting with strangers on a public street, waiting in lines, and communicating with subordinates or superiors'. ${ }^{19}$ These examples reveal that for Berman virtually all normative ordering is law. As a consequence, law is a fuzzy notion and legal pluralism is extraordinarily pervasive.

In a recently published 1,000-plus-page Oxford Handbook on Global Legal Pluralism (2020) that Berman edited, he makes a revealing statement. After acknowledging that global legal pluralism is not really global

${ }^{15}$ Merry, 'Legal Pluralism', 878-9.

${ }^{16}$ By not making his concept of law explicit, Berman shields it from critical scrutiny and denies the need to justify it. Berman has cited my position in support of his, but his position is not mine. He applies an implicit concept of law, while refusing to specify what it is. My position is that no abstract concept or definition of law comes into play in the analysis, implicitly or explicitly; instead, I utilize collective identification of law in the social arena at issue.

17 P. Berman, Global Legal Pluralism: A Jurisprudence of Law beyond Borders (Cambridge University Press, 2012), pp. 41-2.

18 P. Berman, 'The New Legal Pluralism' (2009) 5 Annual Review of Law and Social Science 225-42, at 236.

19 P. S. Berman, 'The Globalization of Jurisdiction' (2002) 151 University of Pennsylvania Law Review 311-545, at 505. 
in reach and not fully pluralist (because he disallows illiberal values), Berman observes: 'Indeed, given the broad (and often undefined) vision of law embraced by legal pluralists, it is perhaps not properly considered "legal" either! "20 Global legal pluralism, under his conception, extends far beyond law to encompass normative pluralism generally. This conceptually confused stance - the source of which lies in sociological legal pluralism - confounds the analysis, as Merry observed three decades ago.

Not only is this understanding of law overinclusive, but global legal pluralism is also all inclusive to an extent that borders on meaninglessness or totalizing ambition. Global legal pluralism apparently purports to encompass all legal orders in the world - local, state, transnational, customary, religious, non-state, etc. - considered together in a vast bottomless bucket. If the assertion is that all legal orders in the world in the aggregate constitutes legal pluralism, it is a true but empty claim; if the claim is that their framework applies to all legal orders in the world considered together or whenever legal multiplicities of any kind arise, it is an audacious claim. Legal pluralism is everywhere, in so many different manifestations and variations that no single framework can capture it all except in the most general descriptive terms.

\subsection{The Problem with Sociological and Jurisprudential Concepts of Law}

After two decades of forcefully promoting legal pluralism, John Griffiths acknowledged that sociological legal pluralism does not work:

In the intervening years, further reflection on the concept of law has led me to the conclusion that the word 'law' could be better abandoned altogether for the purposes of theory formation in sociology of law [...] It also follows from the above considerations that the expression 'legal pluralism' can and should be reconceptualized as 'normative pluralism' or 'pluralism in social control'. ${ }^{21}$

20 P. S. Berman, 'Understanding Global Legal Pluralism: From Local to Global, from Descriptive to Normative', in P. S. Berman (ed.), The Oxford Handbook of Global Legal Pluralism (Oxford University Press, 2020), p. 62, https://papers.ssrn.com/sol3/papers .cfm?abstract_id=3715553.

${ }^{21}$ J. Griffiths, 'The Idea of Sociology of Law and its Relation to Law and to Sociology' (2006) 8 Current Legal Issues 49-68, at 63-4. For helping him come to this realization, Griffiths cites a Dutch article by G. van den Bergh, and two of my articles, 'An Analytical Map of Social Scientific Approaches to the Concept of Law' (1995) 15 Oxford Journal of Legal Studies 501-36, and 'The Folly of the Social Scientific Concept of Legal Pluralism' (1993) 20 Journal of Law and Society 192-217. 
This is a stunning reversal for Griffiths. To renounce a doctrine that brought him academic renown is a testament to his inestimable intellectual integrity. What doomed sociological legal pluralism is the problem of overinclusiveness.

This insurmountable problem is detailed in other work, ${ }^{22}$ so here I present a drastically abbreviated account. Almost all sociological as well as jurisprudential concepts of law involve specifications of function and form (structure). (This is true of all efforts to define social artefacts; for example, a standard definition of a 'chair' is a seat (function) with legs and a back (form).) While numerous variations exist, conceptions of law fall into two basic streams. The first stream encompasses the normative ordering of social associations (focused on law's function) - put forth by Griffiths, who melded Eugen Ehrlich's living law with Sally Falk Moore's semi-autonomous social field. The second stream encompasses institutionalized rule systems (a combination of function and form) - put forth by Marc Galanter, who drew on H. L. A. Hart's union of primary and secondary rules.

The problem with identifying law as the normative ordering of social institutions (the first stream), as Eugen Ehrlich did, including clubs, community organizationsand business partnerships, is that a variety of social mechanisms - customs, morals, habits, reciprocity, etc. - are involved in the ordering of social associations. Defining law in terms of the ordering of associations inevitably encompasses all of this. Jurists at the time rejected his concept of law for this reason. Legal philosopher Morris Cohen objected: 'Ehrlich's book suffers from the fact that it draws no clear account of what he means by law and how he distinguishes it from customs and morals. ${ }^{, 23}$ John Griffiths concluded that Ehrlich's 'theory therefore lacks an independent criterion of "the legal". He seems to take it as obvious which sorts of rules of conduct are legal in character. $^{\text {,24 }}$ Griffiths turned to Sally Moore's semi-autonomous social field (SASF), declaring: 'law is the self-regulation of a semi-autonomous social field'. ${ }^{25}$ However, Moore herself refused to use the label 'law' (she proposed 'reglementation') owing to the same objection: an array of

22 See B. Z. Tamanaha, Legal Pluralism Explained: History, Theory, Consequences (Oxford University Press, 2021).

${ }^{23}$ M. R. Cohen, 'Recent Philosophical Literature: Legal Literature in French, German, and Italian' (1916) 26 International Journal of Ethics 528-46, at 537.

${ }^{24}$ Griffiths, 'What Is Legal Pluralism?', 27.

25 Ibid., 38. 
mechanisms support the rule-bound ordering within social groups that her SASF centres on, including moral norms, reciprocity, potential loss of future benefits and social ostracism. Griffiths understood that his conception of law encompasses a broad continuum of normative ordering, from informal to institutionalized, which led him to conclude that 'all social control is more or less legal. ${ }^{26}$ This position results in the assertion (per Berman) that law encompasses people queuing at a bar or bank.

The conception of law as institutionalized rule systems (the second stream) is an abstract reduction of state legal systems, presenting law as an institutionalized rule system (form) that enacts and enforces norms for social ordering (function). An influential early work on legal pluralism, Marc Galanter's 'Justice in Many Rooms: Courts, Private Ordering, and Indigenous Law' (1981), ${ }^{27}$ builds on H. L. A. Hart's account, defining law in terms of 'the organization and differentiation of norms and sanctions. The differentiation is the introduction of a second layer of control - or norms about the application of norms. ${ }^{28}$ Since society is filled with institutionalized norm-enforcement systems, it follows that law is 'found in a variety of institutional settings - in universities, sports leagues, housing developments, hospitals, etc.. ${ }^{29}$ A century ago, Italian jurist Santi Romano articulated a theory of legal pluralism that takes this line of thinking to its utmost extension, asserting that every institution is a legal order and every legal order is an institution. ${ }^{30}$ Legal orders, in this view, include states, municipalities, corporations, factories, political parties, a prison, a church, a family, a criminal gang and much more. ${ }^{31}$ In a recent essay acknowledging legal pluralism, legal philosopher Joseph Raz likewise identifies law in 'the rules and regulations governing the activities of voluntary associations, or those of legally recognized corporations, and more, including many very transient phenomena, like neighbourhood gangs'. ${ }^{32}$ The legal institutions he has in mind, Raz elaborates, 'are themselves rule-governed, ultimately governed by practice-based

26 Ibid., 39 n. 3.

27 M. Galanter, 'Justice in Many Rooms: Courts, Private Ordering, and Indigenous Law' (1981) 19 Journal of Legal Pluralism 1-48, at 2.

28 Ibid., 19.

29 Ibid., 17-18.

30 S. Romano, The Legal Order (Routledge 2017).

31 For a concise description of Romano's account of law, see L. Vinx, 'Santi-Romano against the State?' (2018) 11 Ethics and Global Politics 25-36.

32 J. Raz, 'Why the State?', in N. Roughan and A. Halpin (eds), In Pursuit of Pluralist Jurisprudence (Cambridge University Press 2017) pp. 136-62, at p. 138. 
rules that determine if not all at least the most important aspects of their constitution, powers, and mode of operation'. ${ }^{33}$ 'In this sense', he continues, 'both the rules of the Roman Republic and those of the University of Wales (disbanded 2011), just as the rules of the United States and of Columbia University, are legal systems. ${ }^{34}$

At bottom, these two streams of conceptions of law involve exercises in relabeling. The first stream relabels the normative ordering of social associations as legal ordering; the second stream relabels institutionalized rule systems as law. Through this relabeling, both approaches immediately produce an immense profusion of law in society. However, their conflation of law with broader social phenomena is theoretically unjustified and results in confusion. Rather than assert that all forms of social control are more or less legal or that all institutionalized rule systems are law, it makes far more sense to assert that multiple forms of social control exist, some of which are law, and that innumerable institutionalized rule systems exist, some of which of are law.

The most straightforward way to identify law from among the multitude of normative orderings and institutionalized rule systems in society is via conventional recognition of what is 'law' (droit, loi, lex, ius, recht, gesetz, diritto, prawo, horitsu, fa, etc.) - which I elaborate further in Section 17.7. The legal systems of France and Massachusetts (etc.) are conventionally perceived as law, but not the internal rule systems of Saint Laurent or Harvard (etc.), which are seen as rule systems specific to the purposes of the organization. International law is law, not because it satisfies abstract criteria of legality based on form, function or some other basis (which no theorist has successfully formulated), but because it is conventionally recognized as law by jurists, political leaders and the public. $^{35}$

\subsection{The Ubiquity of Private Rule Systems and Regulatory Forms}

Transnational legal pluralism scholars have emphasized the ubiquity of private and hybrid regulatory systems operating on the transnational level. Examples include the Court of Arbitration for Sport, ${ }^{36}$ Codex

\footnotetext{
33 Ibid., p. 142.

34 Ibid., p. 143 (emphasis added).

35 For a discussion showing the legal status of international law, see B. Z. Tamanaha, A Realistic Theory of Law (Cambridge University Press 2017), chapter 6.

36 See Chapter 10.
} 
Alimentarius Commission on food standards, voluntary 'soft law' provisions like corporate codes of conduct and UNIDROIT Principles of International Commercial Contracts, International Organization for Standardization and an increasing multitude more. The domestic level has also witnessed a proliferation of private and hybrid bodies carrying out legal functions, with the expansion of private arbitration, private policing (gated communities, universities, sports venues, shopping malls, etc.), private prisons (common in the USA) and private standard setting.

The underlying cause of the explosion of private and hybrid regulation is plain: governments and public bodies lack the capacity to produce and carry out the regulatory activities necessary to deal with countless transactions and intercourse within society and across societies. It has long been common for regulatory standards to be produced by private organizations tied to non-profit consumer associations or trade associations in specific industries, which have the requisite expertise as well as an interest in maintaining quality and safety standards (as well as creating barriers to entry against potential new competitors). Domestic and transnational private standard setting are frequently connected. The American National Standards Institute (ANSI), a private organization created in 1918, accredits standards produced by private standard-setting organizations (many of which have been adopted by state regulators) across a broad swath of matters (electrical standards, chemical standards, public health standards, and so forth); ANSI is a member of the International Organization for Standardization as well as the International Accreditation Forum, propagating American standards more broadly as well as introducing externally produced standards into the USA.

In addition, private organizations have long established and enforced their own rule systems on their employees and consumers and users of their goods and services. Twitter and Facebook famously demonstrated this power in the aftermath of the insurrection on the Capitol building when they banned President Donald Trump from using their platforms for repeated violations of their terms of service. Private companies can also directly enforce state law. Google enforces the EU's 'right to be forgotten law', thus far rendering judgements on over 845,000 requests, delisting 45 per cent of the links. ${ }^{37}$ As Galanter made clear four decades ago, a far greater amount of rule enforcement affecting people's lives takes place within private institutionalized rule systems than through

37 See L. Kelion, 'Google Wins Landmark Right to be Forgotten Case', BBC News (23 September 2019), www.bbc.com/news/technology-49808208. 
state law, and private regulation has vastly increased since that time at domestic and transnational levels.

These private and hybrid regulatory phenomena are undoubtedly important. The issue for theorists and jurists is how they should be characterized. They carry out legal functions, many are structured like legal institutions and their rules and processes often supplement state law. Based on these similarities, leading transnational legal pluralist theorists have swept these phenomena within law - asserting that they are law or that law is a matter of degree, thereby encompassing these regulatory forms. This approach, however, inevitably results in the overinclusiveness problem identified above (including as law universities, hospitals or corporations). A simpler approach is to call them what they are - private and hybrid regulatory forms - noting the manifold respects in which they are law-like and identifying the various ways in which they interact with law. Rather than hold that all forms of regulation are law, it is more sensible to see regulation as a broad category, certain manifestations of which are law (conventionally recognized as such), while many others carry out legal functions but are not law per se. All the same observations can be made by jurists and theorists without stumbling over irresolvable theoretical hurdles involving the concept of law.

\subsection{The Separation of Theory and Practice}

The question 'What is law?' is almost entirely a theoretical exercise. Judges, lawyers and parties engaged in situations with multiple, coexisting forms of law rarely take up this abstract theoretical inquiry. The issues that typically arise in contexts of transnational legal pluralism mainly include questions like these: which of the various forms of law and regulation are relevant to the resolution of the dispute or problem at hand, how much weight should attach to each, and how should conflicts between them be resolved? These issues are resolved not by abstract theoretical inquiries into the concept of law, but by resort to applicable rules of legal relevance and validity, choice of law, conflicts of law and other standard legal mechanisms and analyses that jurists commonly utilize.

Transnational legal pluralist theorists engender confusion when they cross over the line between theory and practice. Roger Cotterrell asserts that lawyers dealing with transnational law need a theory of legal pluralism; after considering different concepts of law by a number of theorists, 
he proposes that law involves institutionalized doctrine. ${ }^{38}$ Berman seeks to develop for jurists 'procedural mechanisms, institutions, and practices that aim to manage, without eliminating, the legal pluralism we see around us' ${ }^{39}$ But it is doubtful that lawyers need or will utilize theoretical concepts of law and legal pluralism, since they have been dealing with these phenomena for many decades without such theories - and how would they decide which is correct among the many theories of law proposed in the literature? Few, if any, judges or lawyers would find useful Berman's assertion that law includes people queuing to get into a bar. While it is common for academic jurists to construct frameworks for lawyers and judges, they typically do so working with the same legal materials, analysing applicable doctrines and legal mechanisms from the internal standpoint of a jurist. In contrast, sociological and theoretical concepts produced from an external standpoint - law as institutionalized normative orders, autopoiesis, networks, entanglement, interlegality, the semi-autonomous social field and other theoretical constructs referred to in the literature - have little application in juridical tasks. Theory and practice are different enterprises.

\subsection{Flaws of a Relational Concept of Law}

Ralf Michaels recently articulated a novel concept of law (or laws) grounded on pluralism as an intrinsic aspect of legal ordering, an account that transnational pluralist scholars have begun to cite. ${ }^{40}$ To Hart's obligatory primary rules addressing social behaviour, and secondary rules used by legal officials to create and apply primary rules, Michaels adds tertiary rules for engaging with external legal orders. Michaels summarizes his definition of law:

A concept of laws, appropriate for a situation of global legal pluralism, must take these challenges [postcolonial customary and religious law] seriously. It should accept the challenge that non-state law can be law. It should reject, however, the claim that non-state law must be viewed as law irrespective of recognition. Instead, it should generalize this

${ }^{38}$ R. Cotterrell, 'Do Lawyers Need a Theory of Legal Pluralism?', in Roughan and Halpin (eds), In Pursuit of Pluralist Jurisprudence, pp. 20-39.

39 P. S. Berman, 'Jurisgenerative Constitutionalism: Procedural Principles for Managing Global Legal Pluralism' (2013) 20 Indiana Journal of Global Legal Studies 665-95, at 668-69.

40 See Chapter 16; R. Michaels, 'Law and Recognition: Towards a Relational Concept of Law', in Roughan and Halpin (eds), In Pursuit of Pluralist Jurisprudence, pp. 90-115. 
recognition requirement and turn it into a general requirement of law - a requirement that exists not just for non-state law, but for state law as well. A legal order, in this definition, requires not two but three kinds of rules. It requires primary rules as its content. It requires secondary rules for its operation. And it requires tertiary rules to establish its relation with other legal orders, whether they are called interface norms, linkage rules or something else. The suggestion that such tertiary rules are a necessary element of legal systems should not be so provocative. ${ }^{41}$

He emphasizes that external recognition by other legal orders is constitutive of whether a given legal order is law: 'Under this theory, translated into legal theory, [external] recognition is constitutive for the identity of law as law. ${ }^{42}$ A given system is not a legal system absent external recognition.

To justify adding tertiary rules Michaels draws an analogy to recognition by other states as the basis for nationhood status under international law. He asserts that 'effectively a legal system cannot operate vis-à-vis other legal systems unless it is recognized by those other legal systems'. ${ }^{43}$ Thus, legal systems are 'mutually constitutive', each becoming law through recognition by the other. This recognition is relative to the interaction between any two systems (hence it is relational). 'Something can be a legal order vis-à-vis one other legal system, but not vis-à-vis another legal system. The nature of a legal system exists in relation to another legal system. ${ }^{44}$ Since all existing state legal systems are externally recognized by other state legal systems via domestic conflicts of law rules (which are tertiary rules), all state legal systems qualify as law in his definition. For reasons I explain, however, his scheme heavily disadvantages non-state law.

Michaels' theory of law has three major problems relevant to legal pluralism, which I articulate up front then illustrate with examples. One problem is that a legal system can be highly effective within a community regardless of whether any external legal system recognizes it, and indeed even when its legal status is affirmatively denied by other

${ }^{41}$ Michaels, 'Law and Recognition', pp. 107-8 (emphasis added). The reference to interface norms is from N. Krisch, Beyond Constitutionalism: The Pluralist Structure of Postnational Law (Oxford University Press, 2012); and the reference to linkage rules is from D. von Daniels, The Concept of Law from a Transnational Perspective (Ashgate, 2010).

42 Michaels, 'Law and Recognition', p. 105.

${ }^{43}$ Ibid., p. 106.

44 Ibid., p. 110. 
legal systems - which is a common occurrence in the history of legal pluralism. Since the vast bulk of what legal systems typically address relate to internal effectiveness, Michaels does not explain why a lack of external effectiveness - which it can function without - justifies the conclusion that an internally effective system is not law. A second problem is that a system can go from being not law until receiving external recognition, then becoming law upon recognition, then not law when recognition is withdrawn, then law again when recognition is restored (and so on) - with its legal status dictated entirely at the whims and interests of the external system (an example follows).

The third problem is a conceptual flaw within the relational theory itself. If a necessary element to qualify as law is external recognition by another legal system, as Michaels contends, then that in itself does not necessitate tertiary rules within the system to establish relations with others. As long as another legal system recognizes it, a given legal system exists even if it does not recognize any other legal system on its part. Since external recognition in his scheme is not conditioned upon reciprocal recognition, there is no logical basis in his theory for requiring tertiary rules within a given system as a necessary feature of law. His account requires only: (1) primary rules of content, (2) secondary rules of operation and (3) receiving external recognition. In Hart's account, to supplement his union of primary and secondary rules, he identified two minimum conditions for the existence of a legal system: the populace must generally obey the primary rules, and legal officials must accept the secondary rules. ${ }^{45}$ Similarly, Michaels' requirement of receiving external recognition does not itself give rise to a third distinct body of rules, and indeed it is not about rules at all. Instead, what his justification calls for is another existence condition: an external legal system must recognize it as law to be effective.

This conclusion reveals that his tertiary rules are neither necessary nor sufficient to constitute law. Assume System A has primary, secondary and tertiary rules - thus possessing the three features he identifies as essential to law. However, if System B does not recognize A as a legal system, it is not a legal system with respect to B. As Michaels put it, 'System A can only determine whether and how it recognizes System $B$ and insofar be constitutive for System B. It cannot determine whether

${ }^{45}$ Hart's justifications for these two conditions were functionality and efficacy. If legal officials do not accept the secondary rules the system cannot function, and if the populace does not obey the primary rules it would be ineffective. 
and how System B recognizes System A. ${ }^{46}$ So having tertiary rules (on top of primary and secondary) is not sufficient to constitute A as law with respect to B. Now assume System A has primary and secondary rules, but not tertiary rules - thus lacking what he identifies as an essential feature of law. If System B nonetheless recognizes A as a legal system, it does count as law for B. So tertiary rules are not necessary to constitute law. It turns out that tertiary rules, Michaels' key addition to Hart's concept of law, are not actually essential to constituting law under his own conceptual scheme.

The conceptual soundness of his theory of laws (positing pluralism and interrelatedness as intrinsic) must be evaluated in terms of whether it makes sense when applied to account for legal phenomena. However, his theory construes law in counterintuitive ways. No system counts as law in isolation or as a general matter because its legal status is constituted only with respect to particular other legal systems that recognize it. It is law in relation to Systems B, C, D, etc., which recognize it, but not law with respect to Systems E, F, G, etc., which do not recognize it. Thus, System A can be law and not law at the same moment (depending on which relation one considers). Moreover, as we just saw, System A's legal status with respect to Systems B, C, and D, etc., can be turned on and off at the sole discretion of each external system. Michaels extrapolates from the correct proposition that System B alone has the power to determine what counts as law for it (a direct implication of legal rules of validity), but ratchets up the theoretical import of this proposition to be 'constitutive' of A's nature as law (an internal point about System B thereby determines the legal nature of System A). This conceptual move transforms a commonplace idea into a source of multiple puzzling implications. ${ }^{47}$

The distorting lens his relational theory provides is evident through application to actual situations of legal pluralism. Consider British treatment of Aboriginal customary law. Upon arrival, they declared Australia terra nullius, with no semblance of law or civil society, a blank legal slate, enabling the colonial government and settlers to seize Aboriginal land

${ }^{46}$ Michaels, 'Law and Recognition', p. 109.

47 A strange implication of this theory, which he acknowledges, is that a legal system cannot exist unless another legal system exists that recognizes it, which itself is not a legal system unless it is recognized by another existing legal system, etc. - thus involving an infinite regress. Michaels dismisses this as a problem for all theories of law, but conventionalist theories based on social recognition do not face an infinite regress. 
because no property rights existed. ${ }^{48}$ This stance conceptually erased the reality that Aboriginal communities had lived for aeons, and continued to live, in accordance with customary law on property rights, personal injuries, marriage and so forth. In Mabo v. Queensland (1992), the Australian court finally recognized that Aboriginal customary law indeed conferred pre-existing property rights that must be respected. ${ }^{49}$ Aborigines had all along viewed and lived in accordance with their customary law, but according to Michaels' relational theory, Aboriginal customary law was not law until external recognition by the Australian legal system constituted it as law, putting its status as law entirely at the leave of the state legal system.

Not only does this stance wholly discount the views and legal practices of Aborigines, it twists the court's inquiry into a logical pretzel. A court in this position is inquiring whether customary law was (or is) a genuine form of law. According to the court, the pre-existing legal status of customary law provides the grounds for its decision, but according to Michaels its legal status follows solely as a consequence of the decision itself. Under his theory, it is not conceptually possible for Aboriginal law to be law prior to recognition, so the court's inquiry into whether it was law (prior to the decision) is nonsensical.

In New Zealand, after a number of violent skirmishes, the British entered the Treaty of Waitangi (1840) with powerful Maori chiefdoms, acknowledging their right to rule in their home areas, and subsequent statutes were enacted recognizing customary law. But this initial recognition was withdrawn after the rapidly increasing settler population became dominant. In an 1877 case, Wi Parata v. Bishop of Wellington, Chief Justice Prendergast declared the Treaty of Waitangi a 'simple nullity', 'worthless', because it had been signed by 'barbarians without any form of law or civil government' incapable of entering a treaty with a civilized nation. ${ }^{50}$ Furthermore, he concluded, the Native Rights Act of 1865 and Native Land Act of 1873, which recognized Maori customary law property rights, were nullities because 'no such body of law existed', and ' $a$ phrase in a statute cannot call what is non-existent in being';

48 See Australian Reform Commission, 'Recognition of Aboriginal Customary Laws (ALRC Report 31)' (1986) paras 39, 60, www.alrc.gov.au/publication/recognition-of-aboriginalcustomary-laws-alrc-report-31/.

${ }^{49}$ Mabo v. Queensland [1992] HCA 23.

50 Wi Parata v. Bishop of Wellington (1877) 3 NZ Jur. (N.S.) S.C., language cited in J. Tate, 'The Three Precedents of Wi Parata' (2004) 10 Canterbury Law Review 273-308, at 293, 294 n. 92. 
subsequent statutes withdrew recognition of customary law. Only in recent decades has Maori customary law again received recognition by the New Zealand state legal system. Ironically, contrary to Justice Prendergast's assertion, according to Michaels' theory, recognition of customary law in a state statute or case does indeed bring previously non-existent Maori law into being - but by the same reasoning the withdrawal of said recognition also extinguishes it. External recognition has a kind of magical ontological power to snap law into and out of existence by declaration, a power wielded by the state legal system, while Maori legal understandings and practices do not matter.

Now I shift from colonial settings to show how the relational theory fails to adequately account for Jewish law and Sharia law in Western legal systems, both mentioned by Michaels. Jewish law recognizes the law of the state, but most state legal systems do not recognize Jewish law as law. In the United States, the decisions of Jewish tribunals (Beth Din) are enforced not as Jewish law, but rather as contractually binding arbitration decisions, no different from contract-based private arbitration generally. From the standpoint of believers, in contrast, these decisions are based on Jewish law. The rules of Beth Din America declare: 'The Beth Din of America accepts that Jewish law as understood by the Beth Din will provide the rules of decision and rules of procedure that govern the Beth Din or any of its panels. ${ }^{51}$ Thus Jewish adherents see two legal systems operating. But according to Michaels' theory, Jewish law is not law unless state law recognizes it as such, which it refuses to do, so state law is the exclusive form of law as far as it is concerned (enforcing private arbitration grounded in state contract law is not recognition of the status of Jewish law as a legal system, nor does it involve conflicts of law rules). A number of states in the USA prohibit courts from recognizing religious law of any kind. Since state legal systems typically assert a monopoly over law, the consequence of his theory is to disqualify non-state law at the outset, eliminating legal pluralism by automatically granting the monopolistic claim of state law.

The situation of Sharia law is even more problematic for Michaels' theory. The UK government recently enacted provisions that would give limited recognition (again as arbitration, not law) to decisions by Sharia tribunals that meet specified criteria, but a number of Sharia councils have expressed reluctance to obtain formal recognition under state law,

51 Rules and Procedures: Beth Din America, p. 5 (emphasis added), https://bethdin.org/wpcontent/uploads/2018/04/BDA118-RulesProcedures_Bro_BW_02.pdf. 
which they consider to be 'un-Islamic'. ${ }^{52}$ In this instance, one form of law rejects an offer of recognition from an external legal system, viewing such recognition as unnecessary and perhaps an insult to its own independent legal status - whereas for Michaels this very rejection disqualifies it from constituting law. Both state law and religious law assert that their law is binding and superior. The direct clash is evident in a fatwa on divorce issued by the Islamic Council of Europe:

In conclusion, I would like to affirm that the divorce issued by the civil court in response to the wife's request is neither a valid divorce nor legitimate marriage dissolution. This means that such a wife remains a wife and is not free to marry another man. Marrying another man while the original marriage is still in place is a violation of Islamic law and a crime. What is more dangerous than this is the fact that all children she gives birth to before obtaining a proper marriage dissolution may be considered to be of the first husband from whom she assumed she had been divorced. Wives who face intolerable situations may seek marriage dissolution by a recognized body that is known and accepted in acting as a judiciary body for Muslims. ${ }^{53}$

State law asserts a parallel position on the opposite side. In February 2020, a British Court of Appeal ruled that a nikah (Islamic) marriage is a 'non-marriage' under state law, so no legally cognizable marital rights attach to Islamic marriages. ${ }^{54}$ This mutual standoff of non-recognition has significant actual consequences: over half of Muslim marriages in the UK, many of which take place in mosques or private homes, are not registered as civil marriages. ${ }^{55}$ Oddly, under Michaels' relational theory, in the relations between the two, neither is a legal system. This is yet another way in which the relational theory conceptually erases manifest legal pluralism.

52 See S. Bano, 'In Pursuit of Religious and Legal Diversity: A Response to the Archbishop of Canterbury and the "Sharia Debate" in Britain' (2008) 10 Ecclesiastical Law Journal 283-309, at 299.

53 S. H. Al-Haddad, 'Fatwa: A Civil Divorce Is Not a Valid Islamic Divorce', Islamic Council of Europe (17 February 2017), https://iceurope.org/fatwa-a-civil-divorce-is-not-a-validislamic-divorce/ (emphasis added).

${ }^{54}$ H. Sherwood, 'Islamic Faith Marriages Not Valid in English Law, Appeal Court Rules', The Guardian (14 February 2020), www.theguardian.com/world/2020/feb/14/islamicfaith-marriages-not-valid-in-english-law-appeal-court-rules.

55 See G. Douglas, N. Doe, S. Gilliat-Ray, R. Sandberg and A. Khan, 'The Role of Religious Tribunals in Regulating Marriage and Divorce' (2012) 24 Child \& Family Law Quarterly 139-57. 
The relational theory of law is antithetical to the thrust of legal pluralism for reasons revealed by these examples. Law throughout history and today is the product of recognition within communities that live by and recognize their own forms of law. This holds for the Indigenous law of the Maori, Australian Aborigines and Native American tribes of North America, as well as Jewish law, Sharia law, Hindu law and other forms of religious law, as well as customary law across Africa, Asia and the Pacific Islands, and many other forms of law. To condition their status as law on recognition by an external legal system, the state legal system in particular, denies communities their own agency in determining what counts as law. Michaels asserts, 'In all but the rarest cases, we will be faced with external recognition from both sides. ${ }^{56}$ This is true among state legal systems, which uniformly recognize one another, but there are many examples past and present of state legal systems not extending reciprocal recognition to customary and religious law.

The examples in this section also illustrate that whether external recognition is extended is not always a matter of comity and respect, but rather is a function of relative power and self-interest. Under the ideal of the monist law state, the state characteristically claims a monopoly over law backed by force of arms. Many forms of community-based law have vigorously disputed this monopolistic assertion for centuries. What Michaels clinically presents as 'external recognition' has often involved existential contests in which a state legal system asserts its dominance over community-recognized forms of law struggling to survive. ${ }^{57}$ His theory gives the state legal system determinative say over legal status (a common assumption of jurists), while many communities around the globe observing non-state law resolutely insist otherwise. Although he is correct that state law determines what counts as law for its own purposes, this does not, and should not, dictate the status of other legal systems on their own terms.

These objections to the relational theory reinforce a point made earlier. Michaels' theory of law might fit state law recognition of other state laws through conflicts of law rules (his scholarly expertise), and it might work for transnational forms of law and regulation, but it is not suitable for many contexts of legal pluralism.

${ }^{56}$ Michaels, 'Law and Recognition', p. 114.

57 Chapters 3 and 14 discuss Indigenous legal orders in Canada struggling to maintain their existence against state declarations of its legal dominance. 


\subsection{Foundations of Legal Pluralism in Conventional Recognition of Law}

It is a commonplace that the social world we inhabit is socially constructed. The social world is the product of our meaningful beliefs, actions and projects, and their intended and unintended consequences. People are born into, assume a place in, partake of and modify existing language, knowledge, social practices and institutions, conventions and technology, generated on an ongoing basis by the community of actors - collectively giving rise to a common social world made up of hospitals, schools, petrol stations, factories, government offices, courts, movie theatres, grocery stores, universities and everything else in society. These are the ubiquitous social phenomena in which we are daily immersed and take for granted. Socially constructed institutions, furthermore, are interconnected within surrounding cultural, social, economic, political, legal, ecological and technological factors, and their existence endures over time (until they expire), developing and changing in relation to exogenous and endogenous factors.

The socially constructed Catholic Church, for example, has changed immensely over its two millennia history. Put in grossly broad strokes: from the claim that Christ designated the bishop of Rome as the head; to the edict establishing Christianity as the official religion of the Roman Empire; to a gradual split between the Western and Eastern churches; to the investiture conflict; to the development of canon law influenced by Roman law; to independent legal authority exercised by the Church across Western Europe on marriage, inheritance, defamation, moral crimes and other matters, alongside regal law, law of the manor, local customary law, etc.; to the Reformation and Counter-Reformation and decades of devastating religious wars; to changing relations with consolidating state systems in Europe and the stripping of ecclesiastical law from authority over the public; to the immensely wealthy Catholic Church today, governing its own affairs, operating its own legal system and ensconced in a sovereign state, Vatican City.

Notice that law and legal pluralism in various respects, evolving over time, have a prominent role in the history of the Catholic Church, interacting with politics, religion, economics and everything else. Accounts of this sort can be provided for all socially constructed, historically enduring, socially interconnected, varying and changing 
manifestations of law throughout history and today. ${ }^{58}$ Whatever people collectively recognize as 'law' (and its translations) is law - recognition of legal status that has attached to innumerable instantiations and variations of law over time: European Union law, United Kingdom law, Scottish law, New York municipal and state law, international law, Halakha (Jewish law), Sharia law, Yapese customary law, Adat law in Indonesia and countless more. These manifestations of law cannot be captured in a single concept of law because their functions and features vary and have changed over time. Informal customary law, and international and transnational law, do not have the same structures as state law, which is why Hart, who explicitly based his concept on state law, concluded that they are not fully fledged law, but pre-legal.

To know what law is for the purposes of legal pluralism does not require an abstract concept or definition of law stating essential or defining features - instead one must inquire into what people in a given social arena collectively (conventionally) identify as law. ${ }^{59}$ As with any social artefact, this inquiry presupposes a rudimentary sense of what is law (likewise, one must begin with a sense of what a chair is to identify what people collectively identify as chairs). Collective senses of what counts as law - including customary and religious law, state law and others - extend back millennia to a shared Western and Near-Eastern tradition (Hammurabi's Code, Greek law, Torah, Sharia, etc.). These notions of law have spread around the world through contact, trade, migration and interaction among peoples generally. Colonization spread state legal systems globally through imposition or imitation, as well as entrenched the notion of customary law in many societies, and international law was a companion of colonization, so these forms of law are familiar in every society around the globe today. Translations for law exist in all classical and contemporary languages - often in multiple terms, like ius and lex, and recht and gesetz, all of which count as conventionally identified law - instantly available on Google Translate.

58 See Tamanaha, A Realistic Theory of Law.

59 Collective recognition involves the shared conventional identification within a group of something as possessing legal status. Since law has substantial connotations of authority within a group, the conventional attachment of this label is relatively restricted, applying to a limited number of phenomena within societies. Under this approach, an interesting question for examination is why in given arenas certain institutional forms are conventionally identified as 'law', while others are not, which may relate to power, rhetorical import, normative authority and other factors. 
In many social contexts today and in the past, multiple collectively recognized forms of law coexist - this is legal pluralism.

The key constitutive factor in particular social constructions of law is conventional recognition within social groups (including groups of legal officials). Conventional recognition determines who counts as legal officials, which specified legal powers they exercise and what they must do for their actions to count as legal. ${ }^{60}$ In highly institutionalized formal legal systems this recognition is tied to official positions occupied by legislators, prosecutors, judges, police, etc., exercising roles with attendant legal powers. But a multitude of socially constructed arrangements of conventionally recognized law exist. In many informal customary law systems, village chiefs or elders preside in collective gatherings and render decisions on the resolution of disputes over matters of property, personal injuries, inheritance, property claims, etc. A single version of law can come in many variations across different contexts. For Islamic law, for example, respected Islamic jurists issue authoritative rulings (fatwa) based on the Quran, Hadith (sayings of the prophet Muhammad) and juristic teachings, although they do not operate within official legal systems; in Iran, an Islamic theocracy, judges occupy positions within the state system applying Islamic law; and in Indonesia, informal Adat tribunals apply mixtures of locally infused Islamic law and customary law. In many contexts, collectively recognized official state legal systems and non-state legal systems both operate, and can be potentially invoked by parties, and sometimes international and transnational forms of law can be invoked as well. That is legal pluralism.

\subsection{Community Law, Regime Law and Cross-polity Law Juxtaposed}

When thinking about situations of legal pluralism, it is useful to keep in mind three roughly distinguishable general categories of bodies of law that have been collectively recognized across many societies, which I descriptively label community law, regime law and cross-polity law. ${ }^{61}$ (These categories are inductively derived generalizations, not analytically derived.) Community law encompasses basic laws and institutions of

60 See N. MacCormick, Institutions of Law: An Essay in Legal Theory (Oxford University Press, 2007), pp. 289-93; J. R. Searle, The Construction of Social Reality (Free Press, 1995), pp. 27-51.

61 The basis for these categories is in Tamanaha, Legal Pluralism Explained. 
social intercourse within communities addressing property, personal injuries, marriage, divorce, sexual restrictions, inheritance, debts and obligations and others; the body of rules through which people arrange their daily affairs. Every society has rules addressing these matters, which vary greatly across societies and change over time. Many existing systems of customary and religious law involve the lengthy continuation of fundamental rules of social intercourse going back many centuries, predating the establishment of state legal systems and evolving to adjust to the presence of the state (and the state to them). Regime laws are laws tied to ruling polities. They constitute, support and enforce the power of the governing regime, including taxation and customs fees, forced labour and military service, laws against sedition, border controls and much more, with governing regimes frequently nested within or encompassing in whole or part other subregimes. Cross-polity laws deal with matters between and across organized polities, consisting of national law (including conflicts of law), international law, transnational law and non-state forms of law that extend across states (like fatwa).

Community law has remained roughly the same in its ambit across place and time. Regime law has expanded enormously in the past two centuries with the consolidation and proliferation of bureaucratic state law and the rise of instrumental lawmaking to address a full range of social, economic and political matters. Cross-polity law has multiplied greatly in conjunction with modern globalization, accelerating in the past half-century to deal with transnational capitalism, transportation, communications, financial transactions, legal and illegal migration, ecological harms and more.

All three categories of law are contained within many unified state legal systems today, though significant exceptions remain. This unification is a recent arrangement. Throughout history, from the Roman Empire to the Ottoman Empire to the British Empire, empires have imposed regime law to maintain imperial interests, while allowing local community-based customary and religious laws and tribunals to address matters of everyday social intercourse. Postcolonial legal pluralism across the Global South today is the continuing legacy of Western imperialism. Large polities that span multiple communities often comprise some arrangement (officially or unofficially) in which pockets of community law continue to function.

Many situations of legal pluralism involve juxtapositions of inconsistent versions of community law, state law and cross-polity law (forms of law from different categories and/or within the same category). In many 
regions across the Global South, people in rural communities manage their affairs through customary law and tribunals, apart from and often inconsistent with official state laws and tribunals. Disputes over the inheritance of land from a male who dies can involve, on the one side, male brothers of the deceased invoking customary law on patrilineal inheritance (community law), backed by the UN Declaration of Rights of Indigenous Peoples (cross-polity law), to support their claim to the land; while on the other side, widows (with help from non-governmental organizations) may invoke state inheritance law on widow's shares (state law), backed by the Convention on the Elimination of All Forms of Discrimination Against Women (cross-polity law). ${ }^{62}$ Across Asia, subsistence farmers invoke customary land tenure rights (community law), clashing with governments and developers seizing land to establish plantations or commercial projects, who invoke transplanted official property rights and titling systems enacted by states (state law) at the behest of the World Bank and Western development agencies (crosspolity organizations transplanting law). European constitutional pluralism involves the juxtaposition of national law of the states (regime law) with EU treaties and law (cross-polity law); the pluralism of coexisting subject matter regimes in international law (WTO, TRIPS, World Health Organization, environmental treaties, etc.) involves multiple examples of cross-polity law with different orientations and objectives, interacting with the laws of nations (regime law) ${ }^{63}$ Legal pluralism is thus manifested around the globe in myriad variations. In pluralistic contexts it is useful to pay attention to three different directions: (1) at the coexisting complex of legal and regulatory institutions and their interaction; (2) at individuals, entities and groups operating within contexts of coexisting legal and regulatory institutions; and (3) at the broader social, cultural, economic, political and legal consequences of the coexisting legal systems (at the consequences of 1 and 2). In the first direction, one should look at the relative power of each set of legal institutions, and the power and resources of the social, economic and political interests that support or align with each; at the normative commitments and personal interests of the officials who operate within each form of law; and at whether, and how, coexisting forms of law operate cooperatively, competitively or combatively (or all three). In the second direction, one should observe how people navigate legal pluralism for normative and strategic reasons:

62 For other combinations, see Chapters 2, 7 and 15.

63 For examples, see Chapters 8, 10 and 12. 
they may resort to a particular form of law for moral, cultural or economic reasons; they may engage in forum shopping to achieve their objectives; they may pit one legal system against another or enlist multiple systems for support. ${ }^{64}$ In the third direction, one should examine the broader cultural, social, economic, political and legal consequences of how the coexisting legal systems interact and how people, entities and groups operate within these contexts. These three directions will expose entanglements between the coexisting forms of law, entanglements between people and coexisting forms of law and entanglements of both with the surrounding interconnected society (culture, economics, politics, etc.). This trifold lens helps expose many of the dynamics at play in contexts of legal pluralism.

\subsection{Transnational Legal and Regulatory Pluralism}

To conclude, let me briefly state five main implications of the foregoing analysis for a reconstructed transnational legal pluralism.

The first lesson, repeated throughout, is that transnational legal pluralism has little in common with postcolonial legal pluralism (first approach) and sociological legal pluralism (second approach). Rather than look to the earlier literature on legal pluralism and emphasize continuity, which tends to mislead more than illuminate, transnational legal pluralists should embrace the understanding that they are jurists constructing a wholly new paradigm to address juristic concerns relating to proliferating forms of transnational law and regulation (public, private, hybrid).

The second lesson is that transnational legal pluralists should not attempt to build on an abstract concept or definition of law (implicitly or explicitly). Not only is a concept of law unnecessary and superfluous (stated next), but engaging in this theoretical project is a roadblock to progress. Theorists who attempt to base transnational legal pluralism on a definition of law will go in circles with other similarly engaged theorists and no prospect of resolution. Be forewarned by the example of John Griffiths - the most often cited theorist of legal pluralism - who finally abandoned this project because it could not be solved.

The third lesson is that what counts as law for transnational legal pluralism is what communities take for granted as law: European Union

64 See Chapter 1. 
law, UK law, individual treaties, national constitutions, international law, human rights, German municipal, state and administrative law, etc. These conventionally recognized manifestations of law are what transnational legal pluralists already discuss. That is why an abstract definition of law is unnecessary. We know what is law because we - jurists, government officials, citizens, native peoples, members of religious communities, etc. - collectively identify them as law. Coexisting clashing conventional identifications of law may exist in given contexts (for example state law and Sharia), but they still count as law when they are seen as such by communities of actors.

The fourth lesson, following directly from the second and third, is that 'transnational legal and regulatory pluralism' is a more suitable label for the concerns of global/transnational legal pluralists. The label 'global legal pluralism' is misleading and should be dropped, for it is neither global nor exclusively legal. The label 'transnational legal pluralism' is problematic because it prompts theorists to explain why what they study counts as law (thereby generating the definitional problem). There is no juristic or conceptual reason to assert that they are law - a superfluous claim that inevitably runs into trouble. Adding 'regulatory' to the label immediately dissolves this issue and recognizes that their work encompasses public, private and hybrid regulatory regimes, a significant amount of which is not collectively considered law - which does not diminish the fact that they are important and accomplish a great deal. They are what they are: private and hybrid regulatory forms that carry out and complement legal functions, and frequently interact with manifestations of law. They bear directly on the concerns of transnational legal pluralists and merit inclusion in the label.

The final lesson, already mentioned but worthy of separate emphasis, is that, beyond state, international and transnational law, many communities also collectively identify and constitute forms of non-state law, mainly manifestations of customary law, religious law and Indigenous law (though other forms exist, like Romani law). These are law as well, which a huge number of people around the globe recognize and live by, especially in rural areas or within insular communities. State legal officials frequently assert state law's claim to supremacy and exclusivity, but this ambition (never fully achieved) does not trump what people collectively recognize, construct and live by as law. State legal systems are themselves collectively recognized forms of law - so state law, international law, transnational law and non-state law are all built on the same foundation of collective recognition. 
The unifying thrust of these five lessons is that we should simplify how we view the complicated contexts of transnational legal and regulatory multiplicities - and the best way to accomplish this is to engage in modest, tailored theorizing that fits the matters at hand. Much of the morass of transnational legal pluralism lamented by Twining is the selfinflicted product of unnecessarily grand theories. The effort to construct a theory that encompasses everything and addresses every context of legal pluralism - as global legal pluralism suggests - is bound to lead us astray. 